\title{
Modelling Zr Transport in Crustal and Mantle Fluids
}

\author{
S. MATTHEWS* \& D. A. SVERJENSKY
}

Earth and Plantary Sciences, Johns Hopkins University, Baltimore, Maryland, USA. (*correspondance: simonmatthews@jhu.edu)

The behaviour of $\mathrm{Zr}$ within the crust and mantle is of importance to both geochemists and petrologists. The mineral zircon has been exploited to a great extent in understanding the evolution of metamorphic terranes. Additionally, the apparent contrast in solubility of $\mathrm{Zr}$ in silicic melts and aqueous fluids is an often exploited tool for identifying the agent of chemical transport between subducted slabs and the mantle wedge.

Using previously published experiments for zircon $\left(\mathrm{ZrSiO}_{4}\right)$ in water [1] and baddeleyite $\left(\mathrm{ZrO}_{2}\right)$ in $\mathrm{NaOH}$ fluids [2], we retrieved the equilibrium constants of the complexes $\mathrm{Zr}(\mathrm{OH})_{4(\mathrm{aq})}$ and $\mathrm{Zr}(\mathrm{OH})_{5}{ }^{-}$or $\mathrm{NaZr}(\mathrm{OH})_{5(\mathrm{aq})}$. Although these species cannot account for the very high zircon solubilities in Na-silicate-rich fluids [2], they can account for the $\mathrm{Zr}$ solubilities in experimental fluids equilibrated with mafic eclogites at 4.0 to $6.0 \mathrm{GPa}$ and $800-1,000^{\circ} \mathrm{C}$ [3]. In these experiments, our models of aqueous $\mathrm{Zr}$ species are consistent with equilibrium with $\mathrm{Zr}$ hosted by rutile. By employing the Deep Earth Water (DEW) model, equations of state were derived for our three aqueous complexes that account well for the experimental $\mathrm{Zr}$ solubilities in water, $\mathrm{NaOH}$, and mafic eclogitic fluids from crustal to upper mantle conditions. Interestingly, $\mathrm{Na}-\mathrm{Si}-\mathrm{Zr}$ complexes previously found in $\mathrm{Na}-$ silicate-rich fluids using XANES and SXRF spectroscopy $[2,4]$ are neither predicted, nor required, to be important in these mafic eclogitic fluids.

Our new models enable us to predict the conditions under which zircon is precipitated and resorbed, potentially offering a new view into the history of fluid-rock interactions. Our models also allow us to make quantitative predictions of $\mathrm{Zr}$ extraction from subducting plates, an important step in quantifying the role of aqueous fluids in the generation of arc volcanics.

\section{REFERENCES}

[1] Bernini et al. (2003), Geochim. et Cosmochim. Acta 119, 178-187. [2] Wilke et al. (2012), Earth \& Planet. Sci. Lett. 349, 15-25. [3] Kessel et al. (2005), Nature 437(7059) 724727. [4] Louvel et al. (2013), Geochim. et Cosmochim. Acta 104, 281-299. 